\author{
$\mathrm{Fe}-17 \mathrm{Mn}-5 \mathrm{Si}-5 \mathrm{Cr}$ 형상기억합금의 형상복원거동 \\ 및 기계적 특성에 미치는 $\mathrm{Ni}, \mathrm{Ti}$ 및 $\mathrm{C}$ 의 영향 \\ 김도형 ${ }^{1,2} \cdot$ 김용환 $^{3} \cdot$ 옥정중 $^{3} \cdot$ 이정훈 ${ }^{4} \cdot$ 박찬희 $^{5} \cdot$ 이욱진 ${ }^{2 *} \cdot$ 박용호 $^{1, *}$ \\ 1부산대학교 재료공학부 \\ 2한국생산기술연구원 \\ 3(주) 디아이씨 \\ 4부경대학교 금속공학과 \\ 5 재료연구소 금속재료연구본부
}

\title{
Effect of Ni, C and Ti Addition on Shape Recovery Behavior and the Mechanical Properties of Fe-17Mn-5Si-5Cr Shape Memory Alloys
}

\author{
Dohyoung Kim ${ }^{1,2}$, Yonghwan Kim ${ }^{3}$, Jeong-Jung Oak ${ }^{3}$, Junghoon Lee ${ }^{4}$, \\ Chan Hee Park ${ }^{5}$, Wookjin Lee ${ }^{2, *}$, and Yongho Park ${ }^{1, *}$ \\ ${ }^{1}$ Department of Materials Science and Engineering, Pusan National University, Busan 46241, Republic of Korea \\ ${ }^{2}$ Korea Institute of Industrial Technology, Yangsan 50623, Republic of Korea \\ ${ }^{3}$ DI Corp., Ulsan 44914, Republic of Korea \\ ${ }^{4}$ Department of Metallurgical Engineering, Pukyong National University, Busan 48547, Republic of Korea \\ ${ }^{5}$ Advanced Metals Division, Korea Institute of Materials Science, Changwon 51508, Republic of Korea
}

\begin{abstract}
Fe-Mn-Si based shape memory alloy is a new functional material that can be used to apply prestress to civil and structural components such as concrete structures. In this study, the effects of alloying elements Ni, $\mathrm{C}$ and $\mathrm{Ti}$ on the mechanical and shape memory properties of the alloy were investigated in detail using a base alloy composition of $\mathrm{Fe}-17 \mathrm{Mn}-5 \mathrm{Si}-5 \mathrm{Cr}(\mathrm{wt} \%)$. Enhanced shape recovery ratio and decreasing strength were observed in the alloy when $4 \mathrm{wt} \% \mathrm{Ni}$ was added. With the further addition of $0.05 \mathrm{wt} \% \mathrm{C}$, the alloy showed even higher shape recovery behavior, although the mechanical strength was lowered by the $\mathrm{C}$ addition. Increasing the carbon content up to $0.1 \mathrm{wt} \%$ led to higher mechanical strength while the shape recovery ratio was decreased slightly. It was shown that the addition of $1 \mathrm{wt} \% \mathrm{Ti}$ can significantly enhance the shape recovery behavior of the alloy. The recovery behavior of the alloy with the co-addition of $0.3 \mathrm{wt} \% \mathrm{C}$ and $1 \mathrm{wt} \% \mathrm{Ti}$ was similar to the alloy without Ti but containing $0.1 \mathrm{wt} \% \mathrm{C}$, even though the $\mathrm{C}$ content was significantly higher. The alloy with the co-addition of $0.3 \mathrm{wt} \% \mathrm{C}$ and $1 \mathrm{wt} \%$ Ti has great potential as functional components in prestressed civil engineering structures, since the yield strength of the alloy is as high as $400 \mathrm{MPa}$ in the solution heat treated condition and can be further improved by aging heat treatments, which precipitate $\mathrm{TiC}$ particles.
\end{abstract}

(Received May 29, 2020; Accepted August 11, 2020)

Keywords: fe-shape memory alloy, Fe-Mn-Si, shape recovery, mechanical property, bending, microstructure

\section{1. 서 론}

형상기억합금은 초탄성 거동 (superelasticity) 및 형상복

- 김도형: 박사과정, 김용환·박찬희·이욱진: 연구원, 옥정중: 상무, 이정훈·박용호:교수 ${ }^{*}$ Corresponding Author: Wookjin Lee [Tel: +82-55-367-9409, E-mail: wkjinlee@kitech.re.kr] ${ }^{*}$ Corresponding Author: Yongho Park [Tel: +82-51-510-3967, E-mail: yhpark@pusan.ac.kr] Copyright (C) The Korean Institute of Metals and Materials
원효과 (shape recovery effect)를 보이는 기능성재료로서 지난 수 십 년간 많은 연구자들에 의해 연구되어 왔으며 이런 독특한 성질은 하중이 가해질 때 나타나는 오스테나 이트 (austenite) 모상으로부터 마르텐사이트 (martensite) 상으로의 응력유기변태 (stress-induced transformation)와 그 역변태에 의해 발현된다고 알려져 있다 [1-4]. 형상기 억합금의 합금조성 등의 특징에 따라 부가된 하중이 제거 되는 즉시 재료의 탄성회복과 더불어 역변태가 일어나 최 
초의 상태로 돌아오는 경우 이를 초탄성이라고 부르며 하 중에 제거된 후 가열 시 추가적인 회복이 일어나는 현상을 형상복원효과라고 한다. 두 현상 모두 응력유기 마르텐사 이트변태 및 그 역변태에 의해서 일어나며, 특히 초탄성 및 형상복원효과가 크게 나타나는 Ti-Ni 기반의 합금이 지 난 반 세기 동안 수많은 연구자들에 의해 연구되어왔다 [5-9]. 뛰어난 초탄성 및 형상복원효과를 갖는 $\mathrm{Ti}-\mathrm{Ni}$ 기반 의 형상기억합금은 높은 형상복원특성에도 불구하고 매우 작은 조성차이에도 상변태 특징이 크게 변화하기 때문에 합금조성을 매우 정밀하게 제어해야 하며 구성원소인 $\mathrm{Ti}$ 와 $\mathrm{Ni}$ 의 가격이 높기 때문에 특수한 목적의 고부가가치산업에 서만 제한적으로 응용되어 왔다.

한 편, Sato등[1,2] 은 단결정 $\mathrm{Fe}-30 \mathrm{Mn}-\mathrm{Si}$ 합금이 약 $9 \%$ 의 형상복원율을 나타내는 것을 발견하였으며, 이는 부 분전위의 이동에 의한 면심입방구조(fcc)의 $\gamma$-오스테나이트 에서 육방조밀구조(hcp)의 $\varepsilon$-마르텐사이트로의 상변화에 의 한 것임을 보고하였다. 철계형상기억합금은 구성원소가 비 교적 저가소재로 되어 있고 철계소재 특성상 대량생산이 용이하기 때문에 토목구조물 등의 구조재료로의 응용이 기 대되며, 따라서 이후 수많은 연구자들에 의해 다양한 조성 의 단결정 및 다결정 철계 형상기억합금이 연구되어 왔다. $\mathrm{Fe}-\mathrm{Mn}-\mathrm{Si}$ 계 형상기억합금의 경우, 매우 넓은 변태 이력 곡 선을 나타내며, 구성원소의 가격이 저렴할 뿐만 아니라 Ti$\mathrm{Ni}$ 기반의 합금에 비해 높은 가공성을 가져 토목구조물용 댐퍼[8,9], pre-strain concrete 구조물[10,11] 등의 기능성 구조재료로의 적용이 기대되고 있다.

현재까지 많은 연구자들에 의해 $\mathrm{Fe}-\mathrm{Mn}-\mathrm{Si}$ 기반 형상기 억합금에 형상복원율 향상 및 내식성 향상을 위하여 다양 한 합금원소를 첨가한 합금계가 연구되어 왔다. 예로 합금 원소 중 $\mathrm{Si}$ 는 합금의 적층결함에너지 (stacking fault energy)를 낮춤으로써 응력유기 마르텐사이트변태를 용이 하게 함으로써 형상복원율을 향상시킨다고 보고되었다 [12,13]. C의 경우 $\gamma$-오스테나이트 기지에 침입형으로 고용 되어 항복강도를 증가시킴으로써 슬립에 의한 영구변형을 억제하여 형상복원율을 증가시킨다고 보고되고 있다 $[14,15]$. 하지만 다량의 C 첨가는 $\mathrm{Ms}$ 온도를 상온 으로부 터 더 멀어지게 하여 형상기억특성에 부정적인 영향을 미 친다. $\mathrm{Cr}$ 과 $\mathrm{Ni}$ 또한 철계형상기억합금의 물성에 좋은 영향 을 미치는 것으로 보고되고 있는데 $\mathrm{Cr}$ 이 첨가됨에 따라 합금의 부식저항성이 높아지고[16], $\mathrm{Ni}$ 은 $\mathrm{Cr}$ 을 첨가함으로 써 발생할 수 있는 $\sigma$ 상의 형성을 억제하면서 내식성을 높여 준다 [17]. 또한 $\mathrm{Cr}$ 과 $\mathrm{Ni}$ 모두 응력유기 마르텐사이트 변태 시작 온도 (martensitic transformation starting temperature,
$\mathrm{M}_{\mathrm{s}}$ )를 변화시킴으로써 상온에서 변형을 부가할 때 응력유 기변태가 원활이 일어나도록 하여 형상복원특성을 높이는 것으로 알려져 있다 [18].

$\mathrm{Fe}-\mathrm{Mn}-\mathrm{Si}$ 기반 형상기억합금에 대한 연구 초기에는, 다 결정 철계형상기억합금은 $\mathrm{Ti}-\mathrm{Ni}$ 기반 합금에 비해 현저히 낮은 형상복원율을 나타내었고, 형상복원율을 높이기 위해 가공-열처리를 반복하는 소위 'training' 이라 불리는 열-기 계적 처리가 필수적인 것으로 보고되었다 $[19,20]$. 하지만 Kajiwara 등[21] 과 Dong 등[22] 은 $\mathrm{NbC}, \mathrm{VC}$ 등의 탄화 물의 석출을 통해 training 과정 없이 높은 형상복원율을 얻 을 수 있다고 보고하였으며, Stanford 등[23] 은 Fe-26Mn$5 \mathrm{Si}-2 \mathrm{Ni}-0.55 \mathrm{Ti}$ 합금계에 다양한 열처리를 하여 금속간화합 물을 석출시키고, 석출물 효과가 형상복원율을 강화시킨다 는 것을 밝혀냈다. 또한 $\mathrm{Fe}-12.5 \mathrm{Mn}-4.5 \mathrm{Si}-9.4 \mathrm{Cr}-6.2 \mathrm{Ni}-$ $0.5 \mathrm{Ti}-0.06 \mathrm{C}$ 합금에서 $\mathrm{TiC}$ 를 석출시킨 합금계에서도 형상 복원율이 training 없이도 향상되는 것이 보고되었다 [24]. 다양한 $\mathrm{Fe}-\mathrm{Mn}-\mathrm{Si}$ 기반 형상기억합금에서 합금원소의 영 향들이 보고되고 있지만, 특정 모합금계에서 각 구성원소 들의 변화에 따른 기계적 특성변화와 형상기억 특성 변화 를 종합적으로 검토한 논문은 아직까지는 보고되지 않고 있다. Dong 등은 $\mathrm{Fe}-17 \mathrm{Mn}-5 \mathrm{Si}-10 \mathrm{Cr}-4 \mathrm{Ni}-(\mathrm{V}, \mathrm{C})$ 합금에서 training 과정 없이 높은 형상복원율을 얻었지만 $10 \mathrm{wt} \%$ 의 $\mathrm{Cr}$ 은 stacking fault energy를 높이는 효과를 보임으로써 $-60{ }^{\circ} \mathrm{C}$ 정도의 $\mathrm{Ms}$ 온도를 보임과 동시에 다량의 $\mathrm{Cr}$ 은 $\sigma$ 상을 형성하여 취성을 띄게 할 수 있고[18], $\mathrm{Cr}$ 이 $10 \%$ 까지 증가된 합금에서도 부동태피막은 형상되지 않았으며, $5 \%$ 의 $\mathrm{Cr}$ 함량에도 기존 철근대비 상당한 부식저항성을 가 지는 것으로 보고되고 있다 [16,25]. 따라서 본 연구에서는 토목구조물 prestressing 등 $\mathrm{Fe}-\mathrm{Mn}-\mathrm{Si}$ 기반 형상기억합금의 기능성 구조재료로의 활용을 염두에 둔 기초연구의 일환으 로 $\mathrm{Cr}$ 의 양을 $5 \%$ 로 줄여 $\mathrm{M}_{\mathrm{s}}$ 온도를 상온과 가깝도록 설 계한 $\mathrm{Fe}-17 \mathrm{Mn}-5 \mathrm{Si}-5 \mathrm{Cr}$ 합금을 모합금으로 하여 니켈, 탄 소, 타이타늄의 함량을 변화시켜 가면서 철계형상기억합금 의 형상기억특성과 기계적 특성에 미치는 합금원소의 영향 을 체계적으로 분석하였다. 합금원소의 영향만을 고려하기 위하여 추가적인 열처리 없이 용체화처리 상태에서의 미세 조직 및 형상기억 특성, 기계적 특징을 분석하였다. 논문에 서 $\mathrm{Fe}-\mathrm{Mn}-\mathrm{Si}$ 계 형상기억합금은 응력을 제거하였을 때 즉 시 회복되는 양이 크지 않으므로 초탄성과 구분하여 의사 탄성 (pseudoelastic)이라는 용어를 사용하였다. 또한 형상 복원효과에 의해 발현된 성질은 형상복원특성 및 형상복원 율로 지칭하였고, 의사탄성거동 및 형상복원거동을 아우르 는 전반적인 형상기억특성을 가리킬 때는 형상기억특성이 
라고 지칭하였다.

\section{2. 실험방법}

본 연구를 위해 $\mathrm{Fe}-17 \mathrm{Mn}-5 \mathrm{Si}-5 \mathrm{Cr}$ 합금을 베이스합금으 로 하여 $\mathrm{Ni}, \mathrm{C}$ 및 $\mathrm{Ti}$ 를 첨가하여 5 가지의 batch를 준비 하였다. 각 batch의 조성은 표 1에 나타내었다. Batch1 과 batch2는 각각 $\mathrm{Ni}$ 의 분율을 1 과 $4 \mathrm{wt} \%$ 로 달리하였고, batch3 과 batch4 는 $\mathrm{Ni}$ 를 $4 \mathrm{wt} \%$ 로 고정하여 $\mathrm{C}$ 를 각각 0.05 와 $0.1 \mathrm{wt} \%$ 첨가하였고, batch 5 는 $\mathrm{C}$ 의 함량이 $0.3 \mathrm{wt} \%$ 이며 추가로 $\mathrm{Ti}$ 가 $1 \mathrm{wt} \%$ 첨가되었다. 시험편은 각 batch의 무게가 약 $250 \mathrm{~g}$ 이 되도록 합금원소들을 평량 하여 진공아크용해로 (Vacuum arc melting furnace)를 이 용하여 잉곳 (ingot)을 제조한 뒤 $1,000{ }^{\circ} \mathrm{C}$ 에서 $1 \mathrm{~h}$ 동안 가열한 후 $10 \mathrm{~mm}$ 까지 열간압연하고, 이후 $1,000{ }^{\circ} \mathrm{C}$ 에서 5 분 동안 가열 후 한 번에 $1 \mathrm{~mm}$ 씩 두께를 줄여가며 두께 가 $6 \mathrm{~mm}$ 가 될 때까지 다단열간압연하여 시험편을 제작하 고 최종적으로 $1,000{ }^{\circ} \mathrm{C}$ 에서 용체화 후 수냉처리하였다.

각 batch 별 상변태 특성을 조사하기 위하여 시차주사열 량계 (DSC, DSC204F1, Netzsch Geratabau $\mathrm{GmbH}$, Geramay)를 이용하여 $10{ }^{\circ} \mathrm{C} / \mathrm{min}$ 의 속도로 $-100{ }^{\circ} \mathrm{C} \sim 300^{\circ} \mathrm{C}$ 범위 내에서 마르텐사이트 변태 시작 온도 (martensite transformation starting temperature, Ms) 및 오스테나이트 변태 시작 온도(austenite transformation starting temperature, $\mathrm{As)}$ 를 조사하였고, 표 2에 나타내었다.

또한 batch별 조성에 따른 상분포를 알아보기 위하여 X-선 회절 (XRD, EMPYREAN, PANalytical BV, Netherlands) 분석을 수행하였다.

Table 1. Chemical compositions of Fe-Mn-Si alloy batches 1-5.

\begin{tabular}{cc}
\hline Batch No. & Composition (wt\%) \\
\hline 1 & Fe-17Mn-5Si-5Cr-1Ni \\
\hline 2 & Fe-17Mn-5Si-5Cr-4Ni \\
\hline 3 & Fe-17Mn-5Si-5Cr-1Ni-0.05C \\
\hline 4 & Fe-17Mn-5Si-5Cr-1Ni-0.1C \\
\hline 5 & Fe-17Mn-5Si-5Cr-1Ni-0.3C-1Ti \\
\hline
\end{tabular}

Table 2. DSC results of Fe-Mn-Si alloy batches 1-5.

\begin{tabular}{ccc}
\hline Batch No. & Ms $\left({ }^{\circ} \mathrm{C}\right)$ & As $\left({ }^{\circ} \mathrm{C}\right)$ \\
\hline 1 & 41.8 & 175.5 \\
\hline 2 & 29.8 & 128.6 \\
\hline 3 & 44.1 & 122.8 \\
\hline 4 & 4.4 & 142.8 \\
\hline 5 & 24.6 & 127.8 \\
\hline
\end{tabular}

제조된 열연바에서 전해방전가공 (Electrical Discharge Machining)을 이용하여 $0.7 \times 3 \times 100 \mathrm{~mm}^{3}$ (그림 1 (c))의 스트립 및 KS B0801 규격의 인장시편[26]을 얻었고, 얻 어진 시험편은 표면을 연마한 후 굽힘시험 및 인장시험에 사용되었다.

합금의 batch별 미세조직을 관찰하기 위하여 가공된 스 트립의 단면을 $\mathrm{SiC}$ paper를 이용하여 단계적으로 연마한 후, $1 \mu \mathrm{m}$ 알루미나 용액과 $0.04 \mu \mathrm{m}$ 실리카 용액으로 최종 연마하고 연마된 시편은 $\varepsilon$-마르텐사이트 상의 확인을 위해 $0.5 \%$ ammonium hydrogen difluoride $\left(\mathrm{NH}_{4} \mathrm{HF}_{2}\right)+1.2 \%$ potassium metabisulfite $\left(\mathrm{K}_{2} \mathrm{~S}_{2} \mathrm{O}_{5}\right)$ 용액으로 에칭한 후 광 학현미경 (OM, Eclipse E200, Nikon, Japan)으로 관찰하 였다.

합금의 형상기억특성을 평가하기 위하여 자체제작한 굽 힘시험 장치를 이용하여 상온에서 굽힘시험을 수행하였으 며, 사용된 굽힙시험장치와 스트립을 그림 1에 나타내었다. 굽힘시험에서 스트립에 인가되는 최대변형량은 빔 이론 (beam theory) 을 통해 다음과 같이 주어진다 [27]:

$$
\varepsilon_{\text {def }}=\frac{t}{2 R_{o}}
$$

이 때, $\varepsilon_{d e f}$ 은 스트립의 최상단과 최하단에서 굴곡에 의 해 인가되는 변형률이고, $t$ 와 $R_{o}$ 는 각각 스트립의 두께 와 인가된 굽힘곡률반경을 나타낸다. 실험에서는 두께 0.7 $\mathrm{mm}$ 의 스트립을 $R_{o}=14.7 \mathrm{~mm}, 7.2 \mathrm{~mm}$ 및 $4.7 \mathrm{~mm}$ 의 세 가지 반경으로 굽힘하였는데, 이는 식 (1)로 계산하면 최대 변형률 $\varepsilon_{\mathrm{def}}=2.3 \%, 4.6 \%$ 및 $6.9 \%$ 에 상응하는 굽힘변형 이다. 이후 굽힘시험된 스트립의 인가하중을 제거한 후 탄 성회복된 스트립의 굽힘반경을 측정하고 $100^{\circ} \mathrm{C}, 150^{\circ} \mathrm{C}$ 및 $200{ }^{\circ} \mathrm{C}$ 의 3 가지 온도에서 $30 \mathrm{~min}$ 간 회복열처리하 여 굽힘반경을 재측정하였다. 그림 2에 스트립의 굽힘변형 인가후 및 온도별 가열에 따른 굽힘반경의 변화를 예를 들 어 나타내었다.

굽힘변형 직후 응력을 제거했을 때 일어나는 의사탄성회 복율 (pseudoelastic strain, $\varepsilon_{p s e}$ ), 온도를 높였을 때 복원되 는 정도인 형상복원율 (shape recovery strain, $\varepsilon_{r e c}$ ) 및 의 사탄성과 형상복원율을 합한 전체복원율 (total recovery strain, $\left.\varepsilon_{t o t}\right)$ 은 다음 식들을 통해 계산하였다.

$$
\begin{aligned}
\varepsilon_{p s e} & =\varepsilon_{d e f}-\frac{t}{2 R_{u}} \\
\varepsilon_{r e c} & =\varepsilon_{d e f}-\varepsilon_{p s e}-\frac{t}{2 R_{h}}
\end{aligned}
$$




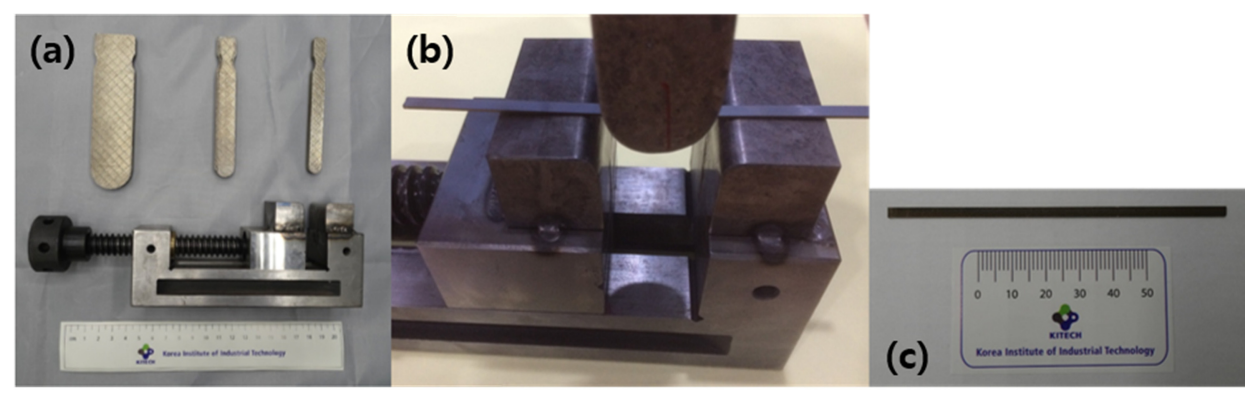

Fig. 1. (a) Laboratory-made bending test equipment for three different bending radii of 4.7, 7.2 and $14.7 \mathrm{~mm}$, (b) bending test and (c) $0.7 \times$ $3 \times 100 \mathrm{~mm}^{3}$ shape memory alloy strip sample for bending test.

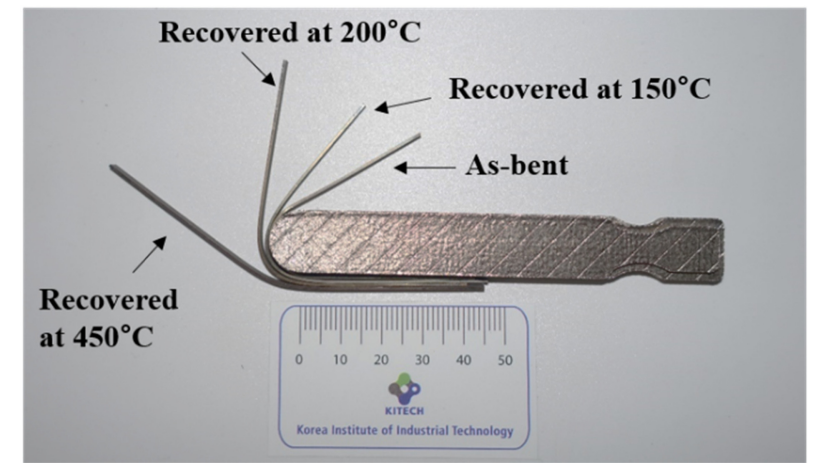

Fig. 2. Appearance of shape memory alloy bending strips in as-bent and recovered at different heating temperatures.

$$
\varepsilon_{t o t}=\varepsilon_{p s e}+\varepsilon_{\text {rec }}
$$

이때 식 2와 3 의 $R_{u}$ 와 $R_{h}$ 는 각각 변형 직후 하중을 제거했을 때와 가열후의 굽힘반경을 나타낸다.

각 batch의 기계적특성은 상온에서 $0.3 \mathrm{~mm} / \mathrm{min}$ 의 속도로 인장시험(UNITECH-T, R\&B Inc., Republic of Korea)을
통해 평가하였다. 연신율의 측정을 위해 부착식 신율계를 사 용하였다.

\section{3. 결과 및 고찰}

\section{1 미세조직}

그림 3 은 용체화 열처리 후 batch 1-5 합금들의 광학 현미경 조직을 나타낸다. 모든 합금들의 미세조직에서 띠 형태의 특징적인 구조가 결정립계 내에 존재하는 것이 관 찰되는데, 이 구조는 $\mathrm{Fe}-\mathrm{Mn}-\mathrm{Si}$ 계 형상기억합금에서 응력유 기변태로 형성된 $\varepsilon$-마르텐사이트 혹은 변태유기소성강에서 체심정방격자(bct) $\alpha$-마르텐사이트가 형성될 때의 미세조 직과 매우 유사하다 [28,29]. 일반적인 $\mathrm{Fe}-\mathrm{Mn}-\mathrm{Si}$ 계 합금에 서 응력유기변태 $\varepsilon$-마르텐사이트는 모상인 $\gamma$ 격자에서 Shockley 부분전위가 이동하면서 적층결함이 수반되어 형 성되므로, 부분전위가 지나간 방향을 따라 일방향으로 뻗 은 얇은 층상구조(lamellar) 형태를 가지는 반면, 응력유기 $\alpha$-마르텐사이트의 경우 상변태 방향이 모상 $\gamma$ 격자의 방

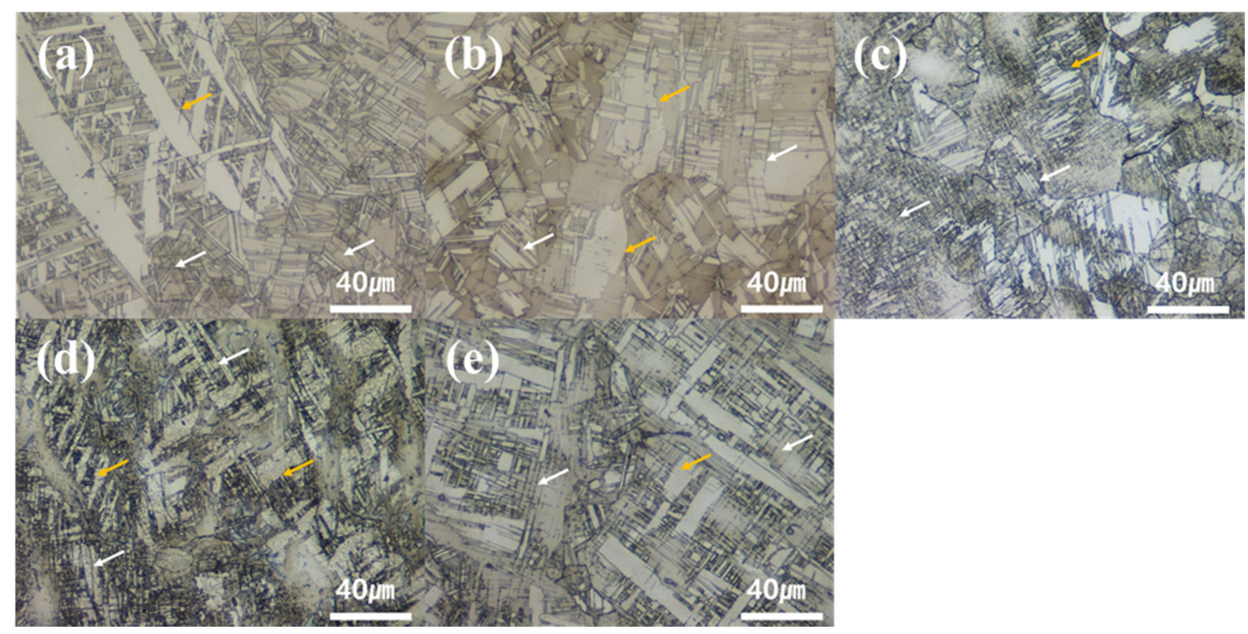

Fig. 3. Color-etched optical microscopic images of Fe-Mn-Si based shape memory alloys (x500). (a) batch 1, (b) batch 2, (c) batch 3, (d) batch 4 and (e) batch 5 . 
향에 의존적이긴 하지만 상변태가 전위의 이동에 수반되지 는 않으므로 완전한 직선 형태가 아닌 lath형태에 가까운 $\gamma / \alpha$ '상간경계를 주로 보인다 [28]. 그림 3의 미세조직에서 는 상기한 두 가지 형태가 모두 관찰되는데, 이 중 $\varepsilon$-마르 텐사이트 혹은 쌍정의 형성과 관련이 있을 것으로 생각되 는 층상구조에 가까운 형태를 흰색 화살표로, $\alpha$-마르텐사 이트의 형성과 관련이 있을 것으로 생각되는 lath 형태의 구조를 노란색 화살표로 각각 표시하였다. 일반적으로 $\mathrm{Fe}-$ $\mathrm{Mn}-\mathrm{Si}$ 계 형상기억합금에서 $\varepsilon$-마르텐사이트가 역변태에 의 해 모두 $\gamma$ 상으로 돌아가는 온도인 오스테나이트 변태 종료 온도 (austenitic transformation finishing temperature, $\mathrm{A}_{\mathrm{f}}$ )는 $400{ }^{\circ} \mathrm{C}$ 를 넘지 않는 것으로 알려져 있다 [30]. 또한 응력유기 $\alpha$-마르텐사이트의 경우에도 $600^{\circ} \mathrm{C}$ 전후의 온도 에서 $\gamma$ 상으로 돌아간다고 보고되고 있다 [31]. 본 연구에 서 사용된 시험편들은 모두 최종열연 후 $1000{ }^{\circ} \mathrm{C}$ 에서 용 체화처리를 거쳤기 때문에 아마도 미세조직은 대부분 $\gamma$-오 스테나이트로 존재할 것이므로, 미세조직에서 관찰되는 $\varepsilon$ 및 $\alpha$-마르텐사이트의 특징적인 형태는 열연과정 혹은 다 단열연과정중 냉각되는 과정에서 발생할 수 있는 상변태의 흔적들인 것으로 사료된다.

합금원소의 미세조직에 미치는 영향을 살펴보기 위해 먼 저 batch 1 과 2 의 미세조직을 비교해 보면, batch 1 에 비 해 $\mathrm{Ni}$ 이 $4 \mathrm{wt} \%$ 이 첨가된 batch 2는 전반적으로는 거의 비슷한 미세조직을 나타내지만 $\varepsilon$-마르텐사이트의 흔적으로 보이는 층상구조의 폭이 확연히 넓어지는 경향을 관찰할 수 있다. 이와 같은 근소한 미세조직변화의 원인은 명확하 지 않지만 표 2에서 볼 수 있듯이 $\mathrm{Ni}$ 첨가에 따라 낮아 진 $\mathrm{M}_{\mathrm{s}}$ 온도로 인하여 적은 양의 $\varepsilon$-마르텐사이트가 생성됨 에 따라 층상구조의 폭이 넓어진 것으로 예상되며 가능성 높은 하나의 원인으로 사료된다. Batch 1, 2와 batch 3, 4 를 비교해 보면 batch 1 과 2 는 특정 결정립에서 $\varepsilon$-마르텐 사이트의 흔적이 없는 조대한 흰색 띠가 관찰되는 반면 batch 3, 4 합금은 검정색 선으로 나타난 매우 미세한 $\varepsilon-$ 마르텐사이트의 특징적인 층상구조가 반복되는 줄무늬가 확연히 관찰된다. 이 결과는 탄소의 첨가가 $\varepsilon$-마르텐사이 트의 형성을 보다 쉽게 일어나게 해 주는 효과를 가져온다 는 것을 암시한다. 이에 비해, $\mathrm{Ti}$ 가 소량 $(1 \mathrm{wt} \%)$ 첨가되 고 상대적으로 높은 탄소분율 $(0.3 \mathrm{wt} \%)$ 을 가지는 batch 5 의 경우 비교적 큰 띠 형태의 결정립 내에 매우 미세한 층상구조가 혼재하는 조직을 보였다. 한 편, $\mathrm{Ti}$ 와 $\mathrm{C}$ 가 첨 가되었음에도 불구하고 조직내에 $\mathrm{TiC}$ 등의 석출물은 관찰 되지 않았는데, 이는 열연후 $1,000{ }^{\circ} \mathrm{C}$ 에서 용체화 및 수 냉처리를 거쳤기 때문으로 생각된다. 따라서 batch 5 에서
대부분의 $\mathrm{Ti}$ 와 $\mathrm{C}$ 는 조직내에 고용되어 있을 것으로 판단 되는데, Stanford 등[24] 이 관찰한 것처럼 $800{ }^{\circ} \mathrm{C}$ 전후 에서 석출경화 열처리를 시행하면 미세한 $\mathrm{TiC}$ 를 분산시 켜 형상복원 특성을 더욱 높일 것으로 판단되지만 본 연구 에서는 batch 5 의 석출경화 열처리에 대해서는 다루지 않 았으며 batch 5의 조성을 응용한 후속연구를 통해 상세히 분석할 예정이다.

\section{2 결정학적 특성}

그림 4 는 Batch 1-5 의 X-선 회절패턴을 나타낸 그래 프이다. Batch 1의 경우 약한 오스테나이트 피크와 함께 $43^{\circ} \sim 45^{\circ}$ 사이에서 $\alpha$ - 및 $\varepsilon$-마르텐사이트 피크가 매우 강 하게 나타난다. $\alpha$ - 및 $\varepsilon$-마르텐사이트 피크는 매우 근접하 게 나타나기 때문에 그림 4에서는 구분이 어렵지만 Dafé 등[32]에 따르면 $\mathrm{Fe}-17 \mathrm{Mn}-0.06 \mathrm{C}$ 합금을 수냉했을때 $\alpha^{\prime}$-마 르텐사이트 보다는 $\varepsilon$-마르텐사이트가 더욱 쉽게 형성된다 고 보고되고 있으며, 회절각도 약 $46.9^{\circ}$ 에 존재하는 $\varepsilon$-마르 텐사이트가 피크가 매우 강한것으로 보아 $\varepsilon$-마르텐사이트 가 형성된 것으로 보여진다. 용체화 처리 상태에서 상당한 양의 $\varepsilon$-마르텐사이트의 형성은 표 2 에서 볼 수 있듯이 batch 1 의 $\mathrm{M}_{\mathrm{s}}$ 온도가 상온보다 높기 때문인 것으로 사료 된다. 반면 $\mathrm{Ni}$ 이 $1 \mathrm{wt} \%$ 에서 $4 \mathrm{wt} \%$ 로 증가한 batch 2 의 경우 $\varepsilon$-마르텐사이트 피크가 상당히 줄어든 것을 알 수 있 다. C가 $0.05 \mathrm{wt} \%$ 추가된 batch 3 는 여전히 높은 분율의 $\varepsilon$-마르텐사이트가 나타나고 있으며, $\mathrm{C}$ 가 $0.1 \mathrm{wt} \%$ 까지 증가 한 batch 4 에서는 $\varepsilon$-마르텐사이트 피크가 거의 사라진 것 을 볼 수 있다. 이러한 경향은 오스테나이트 안정화원소인

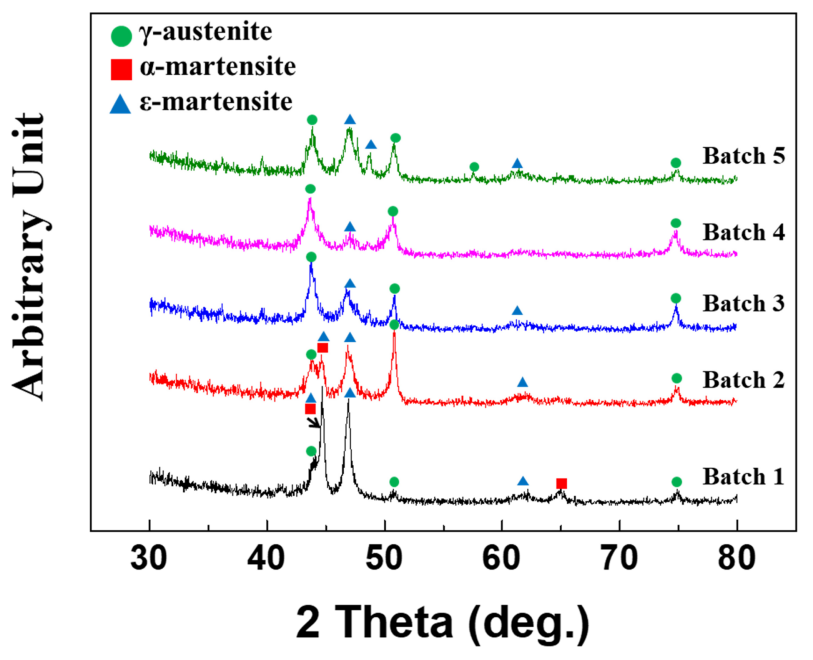

Fig. 4 X-ray diffraction results of Batch 1-5. Green circle, red square and blue triangle indicate $\gamma$-austenite, $\alpha$-martensite and $\varepsilon$ martensite, respectively. 

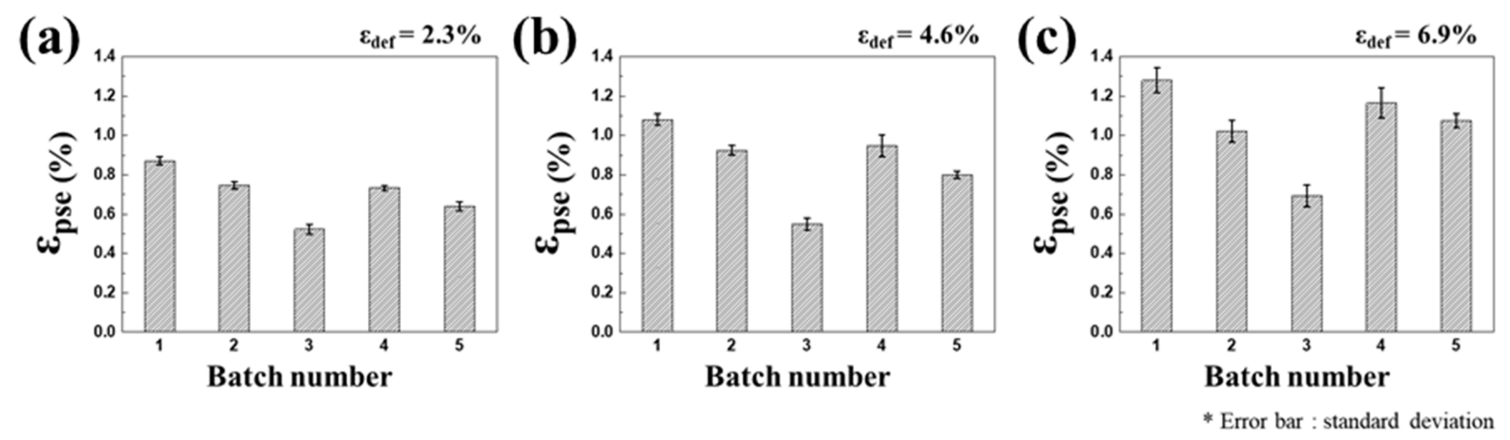

Fig. 5. Measured values of $\varepsilon_{p s e}$ from bending strains, $\varepsilon_{\text {def }}$ of (a) $2.3 \%$, (b) $4.6 \%$ and (c) $6.9 \%$ for Fe-Mn-Si alloy batches $1-5$. The error bars in the graphs represent standard deviations of three individual tests for each data point.

$\mathrm{Ni}$ 및 $\mathrm{C}$ 의 함량이 높아짐으로써 용체화처리 상태에서 오 스테나이트의 안정성이 높아졌기 때문인 것으로 사료된다 [4,14]. 하지만 batch 3 의 경우 $\mathrm{M}_{\mathrm{s}}$ 가 batch 1 보다 높은 $44.06{ }^{\circ} \mathrm{C}$ 인데도 오히려 batch 1 에 비해 상당히 높은 오스테나이트 분율을 나타내고 있다. 이는 단순히 $\mathrm{M}_{\mathrm{s}}$ 온도 만으로 $\varepsilon$-마르텐사이트의 형성능을 비교할 수 없음을 암시 하는 것으로 보인다. 표 2의 Batch 1과 batch 3 의 $\mathrm{A}_{\mathrm{s}}$ 온 도를 비교하면 각각 $175.45{ }^{\circ} \mathrm{C}$ 및 $122.75{ }^{\circ} \mathrm{C}$ 로 batch 3 가 훨씬 낮은 것을 알 수 있으며 따라서 오스테나이트 상 의 상온안정성은 batch 3 의 경우가 더욱 높을 것으로 짐작 된다. 이런 다양한 원인들이 종합적으로 영향을 미쳐서 batch 3 는 batch 1 보다 훨씬 작은 분율의 $\varepsilon$-마르텐사이트 를 상온에서 가지고 있는 것으로 짐작된다. Batch 2 의 조 성에 $0.3 \mathrm{wt} \% \mathrm{C}$ 와 $1 \mathrm{wt} \% \mathrm{Ti}$ 가 추가적으로 첨가된 batch 5 는 다시 $\varepsilon$-마르텐사이트의 피크가 상당히 높아진 것을 알 수 있는데 이는 표 2에서 볼 수 있듯이 $\mathrm{M}_{\mathrm{s}}$ 온도가 다시 상온과 가까워 졌기 때문인 것으로 사료된다.

\section{3 형상기억특성}

\subsection{1 의사탄성회복거동}

그림 5 는 batch $1-5$ 스트립에 굽힘변형 $\varepsilon_{d e f}$ 이 각각 $2.3 \%, 4.6 \%$ 및 $6.9 \%$ 이 되도록 굽힘시험 후 인가하중을 제거하여 회복되는 변형량 $\varepsilon_{p s e}$ 를 측정하여 도식한 그래프 이다. 모든 batch에서 $\varepsilon_{p s e}$ 은 $\varepsilon_{d e p}$ 가 증가함에 따라 거의 선 형적으로 함께 증가하는 경향을 보였다. 실험으로 측정된 회복량은 인가된 $\varepsilon_{d e j}$ 와 Batch에 따라 약 $0.5-1.3 \%$ 의 범 위를 보이고 있는데, 이는 일반적인 철계 소재의 탄성회복 량이 항복강도 $1 \mathrm{GPa}$ 일 경우에도 약 $0.5 \%$ 미만인 사실을 고려할 때 상당한 수준의 의사탄성회복을 보이는 것으로 판단된다. 형상기억합금에서 의사탄성회복은 상온에서의 $\gamma$ 오스테나이트 상의 안정성과 관련되어 있는데, 의사탄성회
복이 크다는 것은 재료의 실제 탄성회복뿐만 아니라 변형 시 형성 된 $\varepsilon$-마르텐사이트가 응력이 제거되는 즉시 $\gamma$-오 스테나이트로 돌아오면서 나타나기 때문이다. 굽힘시험 후 의사탄성거동에 의한 회복을 제외한 단순탄성복원에 의한 복원량은 소재에 인가된 굽힘응력에만 연관되어 있기 때문 에, $\varepsilon_{d e f}$ 의 증가에 따라 아주 소폭만 증가할 것으로 예상된 다. 따라서 실험으로 측정된 $\varepsilon_{p s e}$ 의 $\varepsilon_{d e}$ 에 따른 확연한 증가 는 굽힘변형시 응력유기변태에 의해 형성되는 $\varepsilon$-마르텐사 이트의 양이 굽힘변형량의 증가에 따라 크게 증가했기 때 문으로 보인다.

그림 5의 그래프에서 각 batch별 $\varepsilon_{p s e}$ 를 비교해 보면, batch 1 이 가장 높은 $\varepsilon_{p s e}$ 를, batch 3 이 가장 낮은 $\varepsilon_{p s e}$ 를 모든 굽힘변형량에서 나타내고 있다. Batch 2와 4는 비슷 한 수준의 $\varepsilon_{p s e}$ 를 나타내며 batch 5 의 경우 batch 2 와 4 에 비해 약간 낮은 $\varepsilon_{p s e}$ 를 보인다. 각 batch 사이의 $\varepsilon_{p s e}$ 차이는 합금원소가 달라짐에 따라 $\mathrm{M}_{s}$ 가 달라지기 때문인 것으로 예상할 수 있다. $\mathrm{M}_{\mathrm{s}}$ 가 굽힘시험 온도인 상온과 가까울수록 응력유기 $\varepsilon$-마르텐사이트의 형성이 더 용이하여 더 큰 형 상복원효과를 나타내는데[33], $\mathrm{Ni}$ 및 $\mathrm{C}$ 의 함량이 증가할수 록 $\mathrm{M}_{\mathrm{s}}$ 는 감소한다고 알려져 있다 [4,34]. Batch 1과 2를 비교했을 때 $\mathrm{Ni}$ 함량이 상대적으로 낮은 batch 1 의 경우 그림 4에서 볼 수 있듯이 $\mathrm{M}_{\mathrm{s}}$ 온도가 상온보다 높기 때문 에 용체화처리 상태에서 이미 $\varepsilon$-마르텐사이트가 상당량 형 성되어 있으므로 추가적인 상변태가 batch 2에 비해 어려 워서 응력유기 상변태에 의한 영구변형이 일어나지 못해서 항복강도가 높고, 이로 인해 탄성한계가 높기 때문에 $\varepsilon_{p s e}$ 가 높게 나타났을 것으로 추정되며, 이는 본 논문의 3.4절 에 제시될 합금별 응력-변형률 선도에서도 확인된다. Batch 2 에서는 batch 1 에 비하여 오스테나이트 분율이 높아졌기 때문에 일부 변형량이 상변태에 의한 영구변형으로 수용되 어 $\varepsilon_{p s e}$ 가 낮아진 것으로 보인다. $\mathrm{C}$ 의 함량이 서로 다른 
(a)

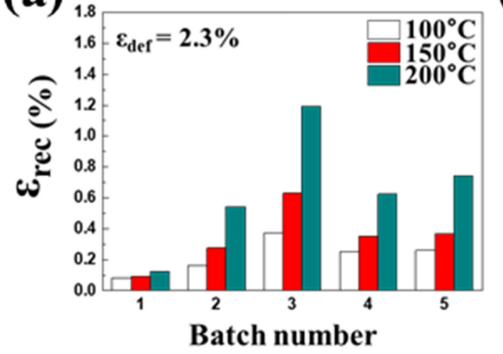

(b)

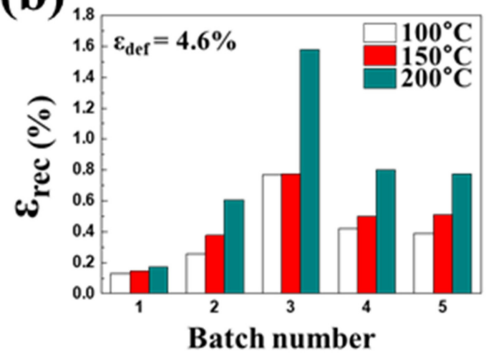

(c)

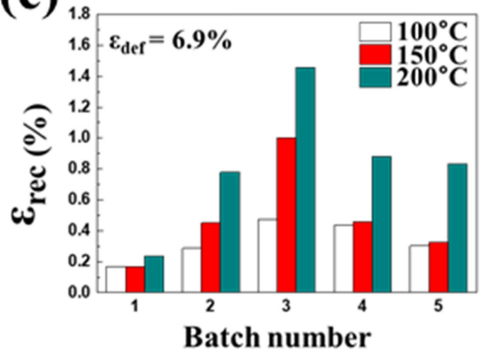

Fig. 6. Measured values of $\varepsilon_{r e c}$ from bending strains, $\varepsilon_{d e f}$, of (a) $2.3 \%$, (b) $4.6 \%$ and (c) $6.9 \%$ after subsequential heating and cooling up to 100,150 and $200^{\circ} \mathrm{C}$ for Fe-Mn-Si alloy batches 1-5.

batch 3 과 4 에서는C 함량이 증가함에 따라 $\varepsilon_{p s e}$ 가 늘어나는 경향을 보이는데, 이는 표 2에서 표시된 $\mathrm{M}_{\mathrm{s}}$ 온도 변화 및 Chen등[34]이 Fe-Mn-Si-Cr-Ni-C 합금계에서 탄소의 분율 을 $0.06 \mathrm{wt} \%$ 와 $0.12 \mathrm{wt} \%$ 로 다르게 한 합금들을 비교 한 연구결과와 잘 일치한다. 참고된 문헌에서 조사된 두 합금의 $\mathrm{M}_{\mathrm{s}}$ 온도는 각각 $-30{ }^{\circ} \mathrm{C}$ 와 $-83^{\circ} \mathrm{C}$ 로, 상온에서 변형 시 $0.06 \mathrm{wt} \%$ 의 탄소를 가진 합금이 상대적으로 높 은 $\mathrm{M}_{\mathrm{s}}$ 때문에 $0.12 \mathrm{wt} \%$ 의 탄소가 첨가된 합금보다 낮은 항복강도와 높은 형상복원률을 보인다고 보고하였다. 특이 한 점은 그림 4 에서 batch 3 와 5 는 모두 높은 분율의 $\varepsilon$ 마르텐사이트가 형성되어 있는데도 불구하고 모두 낮은 $\varepsilon_{p s e}$ 을 나타내며 특히 batch 3 의 경우에는 현저히 낮은 $\varepsilon_{p s e}$ 을 나타낸다는 점이다. 이는 응력유기 $\varepsilon$-마르텐사이트의 분포 와 관련하여 설명될 수 있다. 그림 3에서 볼 수 있듯이, batch 1 이나 2에 비하여 batch 3 의 $\varepsilon$-마르텐사이트는 매우 미세한 검정색 띠 형태로 분포하고 있으며 batch5 또한 미 세한 $\varepsilon$-마르텐사이트들이 관찰된다. Kajiwara 등[35]에 따 르면 이러한 미세한 $\varepsilon$-마르텐사이트가 일부 존재할 경우 응력유기 $\gamma \leftrightarrow \varepsilon$ 변태를 용이하게 하며, 따라서 이를 고려 하면 batch 3,5 가 batch 1이나 2에 비하여 $\gamma \leftrightarrow \varepsilon$ 변 태가 더욱 쉽게 일어날 것으로 사료된다. 이는 합금원소의 변화에 따른 절대적인 $\mathrm{M}_{\mathrm{s}}$ 온도의 변화만으로 형상기억특 성을 예상할 수 없다는 사실을 암시하며, 적층결함에너지 (stacking fault energy)와 관련된 응력유기 마르텐사이트 의 분포나 형상 등 미세조직의 변화와 함께 종합적으로 검토되어야 함을 시사한다. 한편 이러한 $\varepsilon_{p s e}$ 의 증가는 굽 힘변형시 형성되는 $\varepsilon$-마르텐사이트의 상분율이 높음을 의 미하지 않고 회복열처리 시 변태할 수 있는 $\varepsilon$-마르텐사이 트 상의 양 역시 의사탄성변형에 의해 줄어든다는 것을 의미하기 때문에, 온도를 올릴 때 회복되는 $\varepsilon_{\text {rec }}$ 는 batch 1이 다른 batch에 비해 비교적 낮을 것이라고 예상할 수 있다.

\subsection{2 가열에 의한 형상복원거동}

그림 6 는 각 합금 batch를 $2.3 \%, 4.6 \%$ 및 $6.9 \%$ 의 굽 힘변형을 인가한 후 100,150 및 $200{ }^{\circ} \mathrm{C}$ 에서 회복열처 리하여 굽힘반경 변화에서 식(3)을 통해 계산한 $\varepsilon_{r e c}$ 를 나 타낸 그래프이다. 모든 batch에서 형상복원률은 가열온도 가 높아짐에 따라 증가하였으며, 인가된 굽힘변형량 $\varepsilon_{d e}$ 가 $2.3 \%$ 에서 $4.6 \%$ 로 늘어날 때 형상복원률의 절대값이 상대 적으로 늘어나는 경향을 보이지만 $\varepsilon_{d e f}$ 를 $4.6 \%$ 에서 $6.9 \%$ 로 더욱 높였을 때 형상복원률의 절대값에 미치는 영향은 크 지 않은 결과를 보인다. $\varepsilon_{d e}$ 가 높아짐에 따라 형상복원률 의 절대값이 높아지는 원인은 높은 굽힘변형량에서 더 많 은 분율의 $\varepsilon$-마르텐사이트가 형성되었기 때문으로 보인다. 한 편, 그래프에 나타낸 $\varepsilon_{\mathrm{rec}}$ 는 형상복원에 의해 굽힘정도 가 회복되는 절대변형량과 관계되어 있으므로, 인가된 굽 힘변형량 대비 형상이 복원되는 정도는 $\varepsilon_{d e}$ 가 $2.3 \%$ 일 때 가 가장 높고 $\varepsilon_{d e p}$ 가 $6.9 \%$ 일 때에 가장 낮다고도 볼 수 있다.

그림 5 에서 가장 높은 $\varepsilon_{p s s}$ 를 나타냈었던 batch 1은 실 험에 사용된 모든 조건에서 형상복원률이 가장 낮았으며, $\varepsilon_{\text {dep }}$ 가 $2.3 \%$ 일 때 약 $0.1 \%$ 정도의 미미한 형상복원률을 나타내었고 $\varepsilon_{d e p}$ 가 $6.9 \%$, 가열온도가 $200{ }^{\circ} \mathrm{C}$ 일 경우에도 형상복원률은 $0.2 \%$ 언저리의 작은 형상복원률을 나타내었 다. 한 편, 그림 5 에서 가장 낮은 $\varepsilon_{p s e}$ 를 나타냈던 batch 3 의 경우 다른 batch들과 비교하여 가장 높은 회복률을 나 타내는 것이 관찰되며, 가열온도가 $200{ }^{\circ} \mathrm{C}$ 일 때 batch 3 의 형상복원률은 $\varepsilon_{\text {def }}=2.3,4.6,6.9 \%$ 일 때 각각 1.19 , $1.58,1.45 \%$ 로 상당히 높은 수준의 형상복원률을 나타내었 다. Batch 2, 4와 5는 batch 3 보다는 낮지만 가열온도가 $200{ }^{\circ} \mathrm{C}$ 일 때 $0.6-0.8 \%$ 수준의 상당한 형상복원률을 보 였다. 이는 Ni-Ti계열의 높은 형상복원률에 비하면 매우 낮 지만, 소재를 토목구조물 prestressing 등의 구조강화목적으 로 사용할 때에는 일반적으로 $0.3 \%$ 정도의 형상복원 만으 
(a)

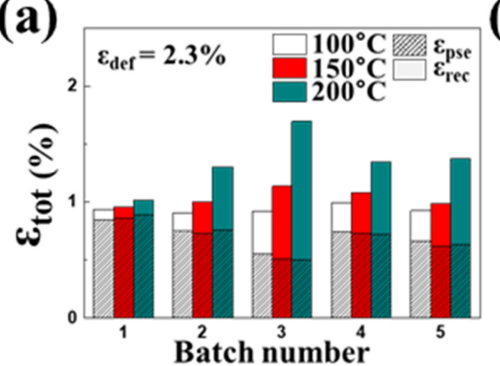

(b)

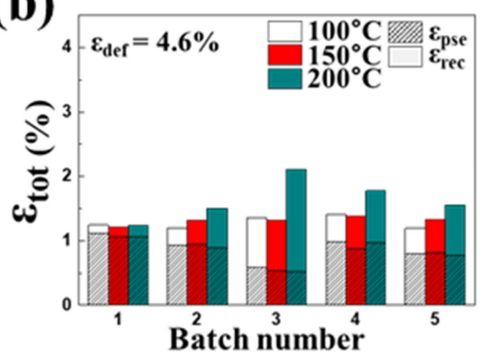

(c)

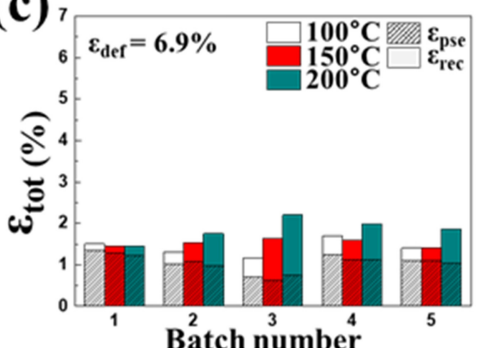

Fig. 7. Measured values of $\varepsilon_{t o t}$ from bending strains, $\varepsilon_{d e f}$, of (a) $2.3 \%$, (b) $4.6 \%$ and (c) $6.9 \%$ after subsequential heating and cooling up to 100,150 and $200{ }^{\circ} \mathrm{C}$ for Fe-Mn-Si alloy batches $1-5$. The maximum values of the $y$-axes in the graphs correspond to the $\varepsilon_{d e f}$.

로도 구조물에 충분한 응력을 부가할 수 있으므로 batch 1 을 제외하면 항복강도 등 다른 특성이 높다면 구조물 강화 목적으로는 사용이 가능한 충분한 형상복원률이다 [36].

합금원소가 형상복원률에 미치는 영향을 알아보면, batch 1 의 매우 낮은 형상복원률은 3.2.1장에서 예상된 바와 같 이 다른 batch에 비해 상온보다 높은 $\mathrm{M}_{\mathrm{s}}$ 온도로 인해 응 력이 부가되기 전에도 상당한 $\varepsilon$-마르텐사이트 분율을 가지 고 있어 응력유기변태가 제한적이기 때문인것으로 사료된 다. Batch 4는 batch 3에 비해 비교적 낮은 형상복원률을 보이는데, $\mathrm{C}$ 분율의 증가에 따른 $\mathrm{M}_{\mathrm{s}}$ 의 감소로 응력유기 $\varepsilon$-마르텐사이트가 batch 3 에 비하여 적게 형성되기 때문으 로 보인다. Batch 2와 3을 비교해 보면 batch 2가 3에 비해 형상복원률이 월등히 낮은데, 기존의 연구들에 따르 면 이런 경향은 $\mathrm{C}$ 첨가로 인한 $\gamma$-오스테나이트 기지의 고 용강화효과로 부분전위가 아닌 완전전위의 이동에 의한 기 지의 영구변형이 억제되어 부분전위의 이동이 상대적으로 활발하게 일어날 때 나타날 수 있다고 보고되고 있다 $[14,15]$. C 분율이 $0.05 \mathrm{wt} \%$ 까지는 기지의 영구변형 억제 효과가 크기 때문에 형상복원률이 증가한다. 하지만 이후 $\mathrm{C}$ 의 분율이 더 올라간 batch 4 에서는 형상복원률이 기지의 소성변형 억제효과 보다는 $\mathrm{M}_{\mathrm{s}}$ 감소에 더욱 크게 의존하면 서 낮아지는 것으로 보인다. Batch 5는 batch 4에 비해 유사하거나 약간 낮은 $\varepsilon_{r e c}$ 을 나타내었는데, 그림 3 에서 나 타난 것처럼 batch 5 는 batch 3 및 batch 4 에 비하여 작 은 결정립 크기를 가지고 있는데, 이는 Ti가 결정립 미세 화를 촉진하기 때문이다 [37]. Peng 등[38]에 따르면 결정 립의 미세화는 입내에 $\varepsilon$-마르텐사이트가 형성될 때 입계의 영향을 많이 받기 때문에 입계로부터 서로 다른 방향으로 성장한 $\varepsilon$-마르텐사이트가 결정립 내부에서 충돌하여 서로 의 $\varepsilon \rightarrow \gamma$ 상변태를 방해하여 형상복원률에 나쁜 영항을 미친다고 알려져 있다. 이런 현상은 서로 다른 결정립 크 기를 가지는 $\mathrm{Fe}-\mathrm{Mn}-\mathrm{Si}$ 계 형상기억합금의 형상복원률을 비
교한 다른 연구에서도 공통적으로 관찰된다 [39]. 하지만 본 연구에서 $\mathrm{Ti}$ 가 $1 \mathrm{wt} \%$ 첨가된 batch 5 에서 현저한 형 상복원율의 감소는 나타나지 않았으며 $\mathrm{C}$ 함량 또한 0.3 $\mathrm{wt} \%$ 까지 증가했음에도 불구하고 $\mathrm{C}$ 함량 증가에 따라 형 상복원률이 감소한다는 Xiong등[40]의 연구결과와도 반대 의 경향을 나타낸다. 표 2에서 볼 수 있듯이 batch 5 의 $\mathrm{Ms}$ 온도는 $24.6{ }^{\circ} \mathrm{C}$ 로 batch 4 의 $4.36{ }^{\circ} \mathrm{C}$ 보다 훨씬 상온 에 가까움을 알 수 있다.이를 고려할 때, batch 5의 batch 2 와 4에 상응하는 높은 형상복원률은 $1 \mathrm{wt} \%$ 첨가된 $\mathrm{Ti}$ 가 $\mathrm{C}$ 분율 증가와 결정립 미세화에 의한 형성복원의 부정적 인 효과들을 상쇄할 만큼 형상복원에 긍정적인 효과를 일 으킨 다고 판단할 수 있다 [24].

그림 5 와 6 에 나타낸 의사탄성에 의한 복원과 가열에 의한 복원을 합한 값인 $\varepsilon_{t o t}$ 을 그림 7 에 실험조건별로 나 타내었다. 굽힘변형량 대비 복원 정도를 직관적으로 관찰 할 수 있도록 그림에서 각 그래프의 $\mathrm{y}$ 축의 최대값은 부가 된 굽힘변형량 $\varepsilon_{d e f}$ 에 맞게 조절되었다. 이 때, 실험으로 관 찰되는 $200{ }^{\circ} \mathrm{C}$ 가열에서의 $\varepsilon_{t o t}$ 값은 미세조직적으로는 200 ${ }^{\circ} \mathrm{C}$ 까지의 가열로 다시 $\gamma$-오스테나이트 상으로 돌아올 수 있는 응력유기 $\varepsilon$-마르텐사이트 상의 상분율과 관계된다. 그 림 6 에서 형상복원률의 절대값은 굽힘변형량이 커지면 늘 어나는 경향을 보였지만, 그림 7 에 나타낸 것처럼 인가된 굽힘변형 대비 $\varepsilon_{t o t}$ 을 관찰해 보면 굽힘변형이 가열에 의해 복원되는 정도는 인가된 변형량에 대비하여 감소하는 경향 이 모든 batch에서 나타난다. $\varepsilon_{d e f}=2.3 \%$ 일 때와 $4.6 \%$ 일 때의 $\varepsilon_{t o t}$ 값들을 비교해 보면, $\varepsilon_{d e f}=2.3 \%$ 일 때 인가된 굽힘변형이 다 회복되지 않음에도 불구하고 $\varepsilon_{d e f}=4.6 \%$ 로 증가시키면 더 많은 응력유기 $\varepsilon$-마르텐사이트가 생성되는 것을 확인할 수 있다. 만약 변형중 형성가능한 $\varepsilon$-마르텐사 이트 variant가 모두 생성된 이후 $\gamma$ 기지의 영구변형이 일어 난다고 가정하면 인가된 변형의 완전회복이 일어나지 않는 $\varepsilon_{d e f}=2.3 \%$ 보다 더 큰 변형을 가하더라도 변형이 $\gamma$ 기지 

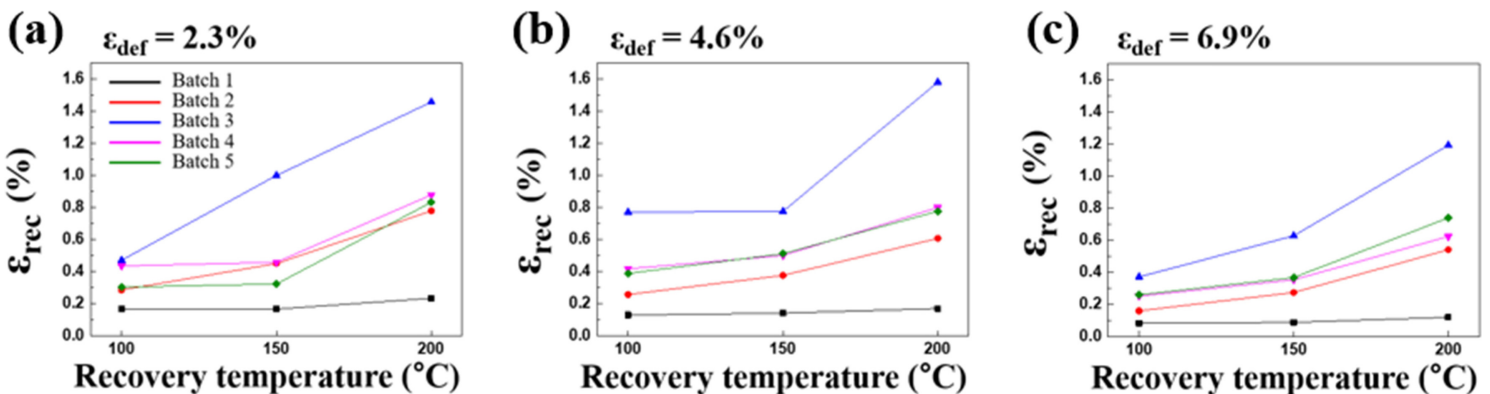

Fig. 8. Measured values of $\varepsilon_{r e c}$ as a function of recovery temperature for bending strains, $\varepsilon_{d e f}$, of (a) $2.3 \%$, (b) $4.6 \%$ and (c) $6.9 \%$ for Fe-MnSi alloy batches $1-5$.

의 소성변형만을 야기할 것이지만 실험 결과는 그렇지 않 으므로, 이 결과는 $\varepsilon_{d e f}<4.6 \%$ 구간에서 변형중 $\gamma$ 기지의 소성변형과 $\varepsilon$-마르텐사이트의 형성이 동시에 일어나는 사 실을 반증한다. 한 편, $\varepsilon_{\text {def }}=4.6 \%$ 인 경우와 $\varepsilon_{d e f}=$ $6.9 \%$ 인 경우의 $\varepsilon_{t o t}$ 값은 모든 조건에서 거의 변화가 없는 데, 이는 $\varepsilon_{d e f}=4.6 \%$ 보다 낮은 인가변형에서 대부분의 생성가능한 응력유기 $\varepsilon$-마르텐사이트 variant가 이미 생겨 서 재료를 더욱 변형하더라도 마르텐사이트의 상분율은 더 이상 늘지 않고 $\gamma$ 기지의 영구변형만 늘어난다는 사실을 뒷받침한다. $\varepsilon_{\text {def }}=2.3 \%$ 일 때 $\varepsilon_{t o t}$ 은 $100{ }^{\circ} \mathrm{C}$ 와 $150{ }^{\circ} \mathrm{C}$ 의 가열온도에서는 모든 batch에서 대략 $1 \%$ 내외의 값을 가지며, $200{ }^{\circ} \mathrm{C}$ 로 가열온도를 올릴 경우 batch 3 의 경 우 $1.7 \%$, batch $2,4,5$ 의 경우 약 $1.3 \%$ 정도의 더욱 높은 $\varepsilon_{t o t}$ 값을 나타내었다. $\varepsilon_{d e f}=4.6 \%$ 과 $\varepsilon_{d e f}=6.9 \%$ 조건에서는 $200{ }^{\circ} \mathrm{C}$ 가열 시 Batch 3 은 약 $2.2 \%$, Batch $2,4,5$ 의 경우 약 $1.8 \%$ 내외의 $\varepsilon_{t o t}$ 값을 보였다.

\subsection{3 가열 온도에 따른 형상복원 거동}

그림 8 은 batch $1-5$ 를 각각 $2.3 \%, 4.6 \%$ 및 $6.9 \%$ 의 $\varepsilon_{d e f}$ 를 갖도록 변형한 뒤, $100{ }^{\circ} \mathrm{C}, 150{ }^{\circ} \mathrm{C}$ 및 $200{ }^{\circ} \mathrm{C}$ 에서 회복열처리했을 때의 가열온도에 따른 $\varepsilon_{r e c}$ 을 나타내고 있 다. 실험의 모든 조건에서 batch 3 의 $\varepsilon_{r e c}$ 가 가장 높게 나 타났으며, batch 1의 경우 거의 회복되지 않았다. Batch 1 을 제외한 모든 합금은 회복열처리 온도가 증가할수록 더 많은 회복이 일어났고, 이는 더 높은 온도에서 더 많은 $\varepsilon$ $\rightarrow \gamma$ 상변태가 일어난다는 것을 의미한다.

만약 $\mathrm{Fe}-\mathrm{Mn}-\mathrm{Si}$ 계 형상기억합금을 토목구조물용 prestressing 등 토목구조물의 강화용으로 쓸 경우 콘크리 트, 몰탈 등 대부분의 토목구조재는 재료의 열화온도가 $150-200^{\circ} \mathrm{C}$ 범위에서 일어나기 때문에 형상기억합금의 가 열온도가 제한된다 [36]. 따라서 그림 8 에 나타낸 결과는 형상기억합금을 콘크리트 등의 강화 목적으로 사용할 때의

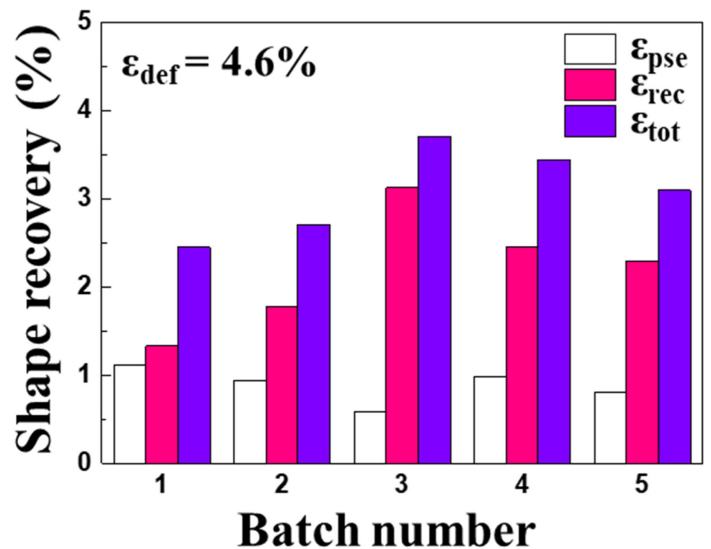

Fig. 9. Measured values of $\varepsilon_{p s e}, \varepsilon_{r e c}$ and $\varepsilon_{t o t}$ upon recovery heating to $450{ }^{\circ} \mathrm{C}$ with $\varepsilon_{d e f}=4.6 \%$.

실용적으로 얻을 수 있는 형상복원이라고 할 수 있다. 가 열온도에 제한이 없는 경우에 얻을 수 있는 최대 형상복원 률을 알아보기 위해 $\varepsilon_{d e f}$ 를 $4.6 \%$ 로 고정하여 $450^{\circ} \mathrm{C}$ 에서 회복열처리 했을 때의 $\varepsilon_{p s e}, \varepsilon_{r e c}$ 및 $\varepsilon_{t o t}$ 를 그림 9 에 나타 내었다. 가열 온도를 $450{ }^{\circ} \mathrm{C}$ 로 올리면 기존 $200{ }^{\circ} \mathrm{C}$ 에서 가열했을 때보다 훨씬 큰 회복이 일어나며 각각 batch 3 은 $1.54 \%$, batch 5 는 $1.52 \%$ 증가하였다. 반면 Batch 2는 $1.16 \%$ 증가하여 Batch 3-5에 비하여 적게 증가하였다. 그 림 9 에서 가열온도를 $450{ }^{\circ} \mathrm{C}$ 로 올리면 $200^{\circ} \mathrm{C}$ 까지는 거의 형상복원을 보이지 않던 batch 1에서도 batch 2에 상당하는 형상복원이 나타나는 것을 관찰할 수 있는데, 이 는 표 2의 $\mathrm{DSC}$ 결과와 같이 batch 1 의 $\mathrm{A}_{\mathrm{s}}$ 온도가 다른 합금에 비하여 높아 $\varepsilon \rightarrow \gamma$ 변태가 늦게 일어나기 때문인 것으로 보이며 batch 2 와 비슷한 수준의 $\varepsilon_{\mathrm{rec}}$ 를 나타내는 것으로 보아 굽힘변형 시 만들어지는 응력유기 $\varepsilon$-마르텐사 이트의 양은 비슷할 것으로 사료된다.

그림 10 은 각 합금을 $\varepsilon_{d e f}=4.6 \%$ 으로 굽힘변형 한 


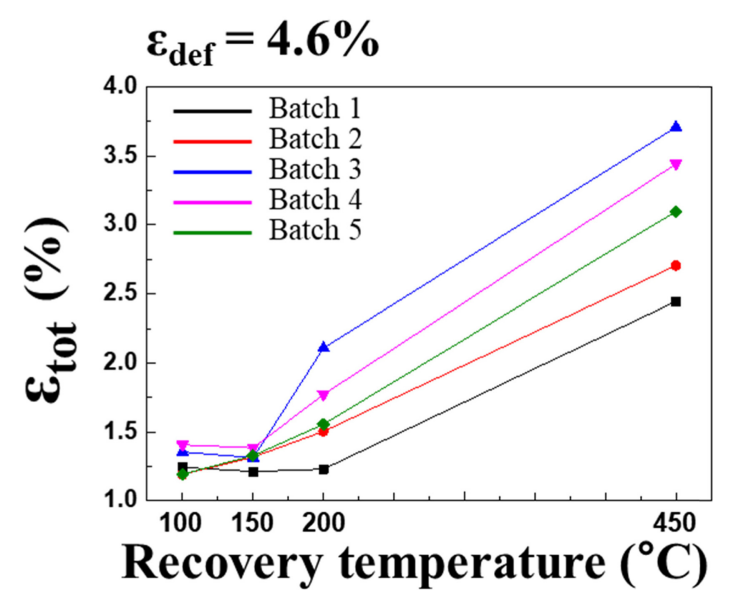

Fig. 10. Change of measured values of $\varepsilon_{t o t}$ upon recovery heating at various temperature, $100{ }^{\circ} \mathrm{C}, 150{ }^{\circ} \mathrm{C}, 200^{\circ} \mathrm{C}$ and $450{ }^{\circ} \mathrm{C}$ with $\varepsilon_{d e f}=$ $4.6 \%$.

후 각각 $100{ }^{\circ} \mathrm{C}, 150{ }^{\circ} \mathrm{C}, 200^{\circ} \mathrm{C}$ 및 $450{ }^{\circ} \mathrm{C}$ 에서 회복열 처리 하였을 때 $\varepsilon_{t o t}$ 를 나타내고 있으며 일부 음의 기울기 를 갖고 있는 영역은 $\varepsilon_{p s e}$ 의 편차때문인 것으로 사료된다. $450{ }^{\circ} \mathrm{C}$ 에서 batch $3-5$ 는 3.1-3.4\%의 높은 $\varepsilon_{t o t}$ 를 나타내며 이는 인가된 굽힘변형 대비 $67-80 \%$ 정도로 높은 형상복원 특성을 나타내고 있다.

\section{4 기계적 특성}

그림 11 은 batch별 조성에 따른 인장 응력-변형률 곡선 을 나타낸다. $\mathrm{Ni}$ 함량이 $1 \mathrm{wt} \%$ 인 batch 1 에 비하여 4 $\mathrm{wt} \%$ 인 batch 2 의 항복강도 및 인장강도가 현저히 줄어들 었다. 이 두 batch 에서는 $\mathrm{Ni}$ 이 증가함으로써 결정립 크기 및 마르텐사이트의 흔적으로 보이는 띠 형태의 경계 폭이 넓어지는 현상이 그림 3의 미세조직에서 관찰되었는데, 이 에 따른 미세구조의 조대화 때문에 항복강도 및 인장강도 가 줄어든 것으로 사료된다. 철강재료의 항복강도는 일반 적인 경우에는 탄소 분율에 따라 고용강화 효과에 의해 증 가하는 경향을 보이지만, 본 실험에서는 특이하게도 $\mathrm{C}$ 가 $0.05 \mathrm{wt} \%$ 첨가된 Batch 3의 경우 Batch 2에 비해 항복강 도가 더욱 크게 감소하였고, Batch 4와 5는 Batch 2와 비 슷한 항복강도를 보였다. 한 편, 항복점 후의 소성영역에서 의 응력-변형률 곡선 기울기는 batch 1 과 2 는 거의 유사하 지만 batch 3-5는 이들과 완전히 상이한 기울기를 보인다.

위 실험 결과들은 $\mathrm{Fe}-\mathrm{Mn}-\mathrm{Si}$ 계 형상기억합금의 인장거동 이 일반적인 결정립 미세화 기구와 고용강화 기구만으로 설명하기 어렵다는 것을 지적한다. 이 합금계에서 항복점 으로 보이는 부분은 $\gamma$ 기지의 소성변형 보다는 주로 응력 유기 $\varepsilon$-마르텐사이트 변태가 시작되는 지점으로 간주되는

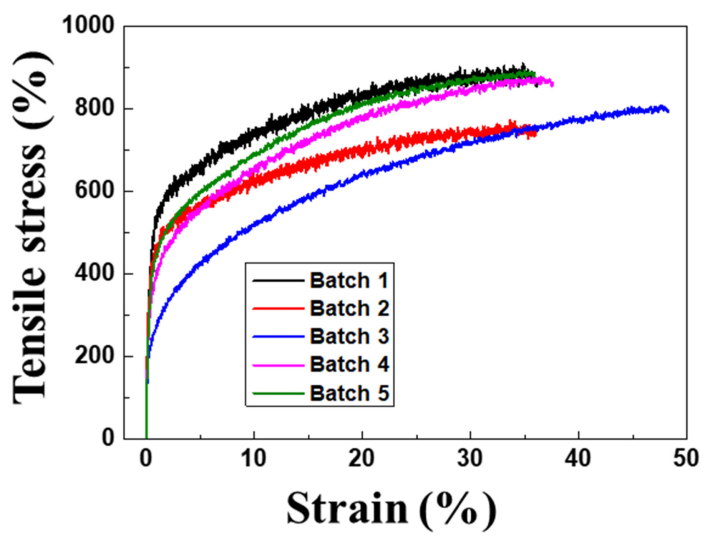

Fig. 11. Tensile stress-strain curves of Fe-Mn-Si alloy batches 1-5.

데[10], 조사된 합금계중 형상복원률이 가장 높은 batch 3 의 경우 $\varepsilon$-마르텐사이트 변태가 다른 batch에 비해 비교적 쉽게 일어날 것이라고 예상할 수 있다. 이를 고려하면 batch 3의 낮은 항복점은 다른 batch에 비해 더 낮은 응 력구간에서 $\gamma \rightarrow \varepsilon$ 상변태가 일어나기 때문일 것으로 판단 된다. 소성영역에서의 batch 3-5의 상이한 응력-변형률 곡 선 기울기 역시 batch 1과 2에 비해 bacth 3-5에서 더 낮은 응력구간에서 $\gamma \rightarrow \varepsilon$ 상변태가 활성화 되기 때문으로 이해할 수 있다. 한편 batch 4 및 5 는 높은 탄소분율로 오스테나이트 기지의 고용강화효과 및 그림 3 (e)에서 나 타난 $\mathrm{Ti}$ 첨가에 의한 결정립 미세화 효과에 의해 $\gamma$ 기지의 강도가 batch 3 에 비해 높을 것으로 예상되는데, 이와 함 께 $\mathrm{C}$ 와 $\mathrm{Ti}$ 의 첨가에 의해 $\gamma \rightarrow \varepsilon$ 상변태가 batch 3 과 비 교하였을 때 비교적 높은 응력에서 활성화 되는 거동을 함 께 보이기 때문에 인장 응력-변형률 곡선이 batch 3 에 비 해 상당히 높다.

본 실험에서 토목구조물 prestressing 목적으로 사용이 가능한 수준의 형상복원률을 보인 batch 2-5 중 batch 2, 4, 5 합금들은 항복강도 약 $400 \mathrm{MPa}$ 의 준수한 수준의 강도를 용체화상태에서 보였으며, 파단연신률 또한 $35 \%$ 정 도로 토목용 구조부재로 사용하기 충분한 수준을 보였다. Leinenbach 등 [41]과 Wang 등[39]의 연구에 따르면 토 목구조물 prestressing 목적으로 연신된 형상기억합금의 양 쪽 끝을 구속한 상태에서 가열할 때 발생하는 회복응력은 형상복원률 보다는 항복강도의 영향을 더 많이 받는다. 따 라서 토목구조물용 prestressing 등 구조물의 강화 목적으 로 사용할 때에는 상당한 수준의 항복강도와 형상복원률을 동시에 보이는 batch $2,4,5$ 등의 합금계를 사용하는 것 이 바람직해 보인다. 한 편, batch 1 과 3 의 경우 각각 높 은 의사탄성거동과 높은 형상복원률을 보이는 특징을 가지 
고 있으므로 이와 같은 특성이 필요한 댐퍼구조체 혹은 파 이프 클램핑 등에 적용이 용이할 것으로 생각된다. 특히 batch 3 의 경우 추후 열, 냉간압연 및 후열처리 효과에 대 한 연구를 통해 높은 형상기억특성과 준수한 항복강도를 동시에 가지는 합금을 개발할 수 있을 것으로 기대된다. Batch 5 는 $\mathrm{Ti}$ 와 $\mathrm{C}$ 를 다량으로 포함하고 있는데, 이 두 원 소의 첨가효과는 본 연구의 결과들을 고려할 때 각각 $\mathrm{Ti}$ 는 형상복원률을 높이는 효과를, $\mathrm{C}$ 는 형상복원률을 낮추는 효 과를 가지고 있는 것으로 판단되나 batch 5 의 조성에서는 이 두 효과가 서로 상쇄되어 batch 4 와 거의 유사한 형상 복원특성을 보였다. 따라서 $\mathrm{Ti}$ 는 $\mathrm{TiC}$ 석출 없이도 $\gamma$ 기지의 항복강도를 높이고 다량의 $\mathrm{C}$ 가 함유된 상태에서도 상당한 수준의 형상복원특성을 나타내게 하는 효과적인 합금원소 임을 알 수 있으며 이러한 거동은 기존의 연구에서는 밝혀 지지 않았던 사실이다. 향후 열처리를 통해 $\mathrm{TiC}$ 를 $\gamma$ 기지 내에 석출시켜 추가적인 석출경화 효과를 노릴 수 있기 때 문에 batch 5 는 기능성 구조재료로 활용성이 batch 4 에 비해 더욱 높을 것으로 생각된다.

\section{4. 요 약}

본 논문에서 $\mathrm{Fe}-17 \mathrm{Mn}-5 \mathrm{Si}-5 \mathrm{Cr}$ 모합금에 대한 합금원소 의 첨가가 형상복원특성 및 기계적특성에 미치는 영향에 대해 연구하였다. $\mathrm{Ni}, \mathrm{C}$ 및 $\mathrm{Ti}$ 의 첨가는 그 종류와 함량 에 따라 서로 다른 특성을 나타내었으며 주요 결과는 다음 과 같이 요약된다.

1) $\mathrm{Fe}-17 \mathrm{Mn}-5 \mathrm{Si}-5 \mathrm{Cr}$ 합금에 $\mathrm{Ni}$ 을 첨가하면 $\mathrm{Ni}$ 함량이 $1 \mathrm{wt} \%$ 에서 $4 \mathrm{wt} \%$ 로 증가했을 때 비교적 큰 형상복원률 의 증가와 함께 항복 및 인장강도가 크게 감소하였다. $\mathrm{Ni}$ 함량 증가에 따른 항복강도의 감소는 결정립 및 열연과정 중 생성되었을 것으로 생각되는 마르텐사이트 아결정상 구 조의 폭이 증가했기 때문이며 형상복원률의 증가는 $\mathrm{M}_{\mathrm{s}}$ 가 상온이하로 감소하면서 $\gamma \hookrightarrow \varepsilon$ 변태가 가능해졌기 때문인 것 으로 사료된다.

2) $\mathrm{C}$ 의 첨가량이 늘어남에 따라 형상복원특성은 0.05 $\mathrm{wt} \%$ 까지는 늘어나다가C함량이 $0.1 \mathrm{wt} \%$ 까지 증가하면 감 소하는 양상을 보였다. $\mathrm{C}$ 가 $0.05 \mathrm{wt} \%$ 첨가된 합금은 조사 된 합금계 중 가장 낮은 항복강도와 함께 가장 큰 형상복 원률을 보였으며, 이는 $\mathrm{C}$ 의 고용으로 인해 $\gamma$ 기지가 고용 강화되어 완전전위의 이동에 의한 영구변형보다 부분전위 의 이동에 의한 상변태로 야기되는 변형이 더 용이해졌기 때문으로 설명 가능하다. C함량이 $0.1 \mathrm{wt} \%$ 까지 증가하였 을 때 항복강도는 증가하였으나 형상복원률은 크게 감소하
였으며 이는 $\mathrm{C}$ 함량 증가에 따라 $\mathrm{M}_{\mathrm{s}}$ 온도가 상온에서 더 멀 어졌기 때문으로 보인다.

3) $\mathrm{C}$ 와 $\mathrm{Ti}$ 가 각각 $0.3 \mathrm{wt} \%, 1 \mathrm{wt} \%$ 첨가된 합금의 경우 $1,000{ }^{\circ} \mathrm{C}$ 다단열연 후 $1,000{ }^{\circ} \mathrm{C}$ 용체화 처리 했을 때 미 세조직내에 $\mathrm{TiC}$ 등의 석출물은 발견되지 않았으며 따라서 아마도 첨가된 $\mathrm{Ti}$ 와 $\mathrm{C}$ 는 대부분 $\gamma$ 기지 내에 고용되어 있 을 것으로 생각되었다. $\mathrm{Ti}$ 가 첨가된 합금은 같은 조건에 서 제조된 다른 합금에 비해 결정립이 미세화되었고 상당 히 높은 항복 및 인장강도를 보였다. 또한 $0.3 \mathrm{wt} \%$ 의 높 은 탄소함량을 가지고 있음에도 불구하고 인장변형 $4.6 \%$ 에 상당하는 굽힘변형 인가시 $200{ }^{\circ} \mathrm{C}$ 의 가열로 약 $0.8 \%$, $450{ }^{\circ} \mathrm{C}$ 의 가열로 약 $2.3 \%$ 정도의 상당한 수준의 형상복원 특성을 보였다. 이는, 이 합금이 $400 \mathrm{MPa}$ 정도의 높은 항 복강도를 보인 것을 함께 고려하면, 토목구조물 prestressing 등 형상복원특성을 응용한 구조물의 응력부가 에는 충분한 수준의 형상복원 특성이다.

4) 상기 합금은 $0.3 \mathrm{wt} \%$ 의 다량의 $\mathrm{C}$ 를 함유하고 있음 에도 불구하고 $\mathrm{C}$ 의 함량이 $0.1 \mathrm{wt} \%$ 인 경우와 비교하여 현저한 형상복원특성의 저하가 없었다. 이는 추가로 합금 화된 Ti가 $\gamma$ 기지에 고용되었을 때 형상복원특성을 향상시 키기 때문인 것으로 사료되며 이는 기존의 연구에서 보고 되지 않은 거동이다. 또한 이 합금은 향후 적절한 열처리 를 통해 형상복원특성의 저하가 거의 없이 $\mathrm{TiC}$ 의 석출에 의한 석출경화효과 역시 노릴 수 있을 것으로 예상되어 향 후 본 합금의 토목구조물 강화용 기능성 구조재료로의 응 용을 기대할 수 있다.

5) 본 연구에서 조사된 개별합금원소의 영향은 향후Fe$17 \mathrm{Mn}-5 \mathrm{Si}-5 \mathrm{Cr}$ 계 형상기억합금의 형상복원특성, 의사탄성 거동 및 기계적 물성을 목적에 맞게 발현하는 데 기초지식 으로 활용될 수 있을 것으로 기대된다.

\section{감사의 글}

본 연구는 국토교통부/국토교통과학기술진흥원의 지원으 로 수행되었음(과제번호 19CTAP-C151899-01).

\section{REFERENCES}

1. A. Sato, Y. Yamaji, and T. Mori, Acta Metall. 34, 287 (1986).

2. A. Sato, E. Chishima, Y. Yamaji, and T. Mori, Acta Metall. 32, 539 (1984).

3. Z. Z. Dong, S. Kajiwara, T. Kikuchi, and T. Sawaguchi, Acta Mater. 53, 4009 (2005). 
4. H. Otsuka, H. Yamada, H. Tanahashi, and T. Maruyama, Mater. Sci. Forum 56-58, 655 (1991).

5. Y. Liu, Acta Mater. 95, 411 (2015).

6. S. Miyazaki and K. Otsuka, Metall. Mater. Trans. A 17A, 53 (1986).

7. S. M. K. Otsuka and Y. Suzuki, Scr. Metall. 15, 287 (1981).

8. J. Kim and K. Hwang, Korean J. Met. Mater. 57, 562 (2019).

9. P. L. Narayana, Seong-Woong Kim, Jae-Keun Hong, N. S. Reddy, and Jong-Taek Yeom, Met. Mater. Int. 24, 919 (2018).

10. F. Yoshinaka, T. Sawaguchi, N. Ilya, S. Takamori, and N. Nagashima, Procedia Struct. Integr. 19, 214 (2019).

11. N. Nagashima, T. Sawaguchi, and K. Ogawa, Procedia Struct. Integr. 2, 1435 (2016).

12. W. J. Lee, B. Weber, and C. Leinenbach, Constr. Build. Mater. 95, 600 (2015).

13. W. J. Lee, B. Weber, G. Feltrin, C. Czaderski, M. Motavalli, and C. Leinenbach, Smart Mater. Struct. 22, 125037 (2013).

14. V. G. Gavriljuk, V. V. Bliznuk, B. D. Shanina, and S. P. Kolesnik, Mater. Sci. Eng. A 406, 1 (2005).

15. X. Tian and Y. Zhang, Mater. Sci. Eng. A 516, 78 (2009).

16. V. V. Bliznuk, V. G. Gavriljuk, B. D. Shanina, A. A. Konchits, and S. P. Kolesnik, Acta Mater. 51, 6095 (2003).

17. Y. H. Wen, M. Yan, and N. Li, Scr. Mater. 50, 441 (2004).

18. W. J. Lee, R. Partovi-Nia, T. Suter, and C. Leinenbach, Mater. Corros. 67, 839 (2016).

19. M. Murakami, H. Yamada, T. Maruyama, and H. Tanahashi, ISIJ Int. 30, 674 (1990).

20. L. J. Rong, D. H. Ping, Y. Y. Li, and C. X. Shi, Scr. Metall. Mater. 32, 1905 (1995).

21. Y. Watanabe, Y. Mori, and A. Sato, J. Mater. Sci. 28, 1509 (1993).

22. C. Y. Chung, C. Shuchuan, and T. Y. Hsu, Mater. Charact. 37, 227 (1996).

23. S. Kajiwara, D. Liu, T. Kikuchi, and N. Shinya, Scr. Mater. 44, 2809 (2001).

24. Z. Dong, U. E. Klotz, C. Leinenbach, A. Bergamini, C. Czaderski, and M. Motavalli, Adv. Eng. Mater. 11, 40
(2009).

25. N. Stanford and D. P. Dunne, Mater. Sci. Eng. A 454-455, 407 (2007).

26. N. Stanford and D. P. Dunne, J. Mater. Sci. 41, 4883 (2006).

27. J. Joo, H. Lee, D. Kim, W. Lee, and J. Lee, J. Korean Inst. Surf. Eng. 52, 364 (2019).

28. KSA, Test Pieces for Tensile Test for Metallic Materials; KS B0801, Seoul (2007).

29. S. C. Mao, X. D. Han, Y. B. Tian, J. F. Luo, Z. Zhang, Y. Ji, and M. H. Wu, Mater. Sci. Eng. A 498, 278 (2008).

30. D. Raabe, D. Ponge, O. Dmitrieva, and B. Sander, Adv. Eng. Mater. 11, 547 (2009).

31. J. Chiang, J. D. Boyd, and A. K. Pilkey, Mater. Sci. Eng. A 638, $132(2015)$.

32. L. Meng and X. Zhang, Mater. Res. 22 (2019).

33. P. J. Gibbs, E. De Moor, M. J. Merwin, B. Clausen, J. G. Speer, and D. K. Matlock, Metall. Mater. Trans. A Phys. Metall. Mater. Sci. 42, 3691 (2011).

34. S. S. F. De Dafé, F. L. Sicupira, F. C. S. Matos, N. S. Cruz, D. R. Moreira, and D. B. Santos, Mater. Res. 16, 1229 (2013).

35. H. Peng, J. Chen, Y. Wang, and Y. Wen, Adv. Eng. Mater. 20, 1 (2018).

36. J. Chen, H. B. Peng, Q. Yang, S. L. Wang, F. Song, and Y. H. Wen, Mater. Sci. Eng. A 677, 133 (2016).

37. S. Kajiwara, Mater. Sci. Eng. A, 273-275, 67 (1999).

38. A. Arabi-Hashemi, W. J. Lee, and C. Leinenbach, Mater. Des. 139, 258 (2018).

39. Y. Han, J. Shi, L. Xu, W. Q. Cao, and H. Dong, Mater. Des. 34, 427 (2012).

40. H. Peng, G. Wang, S. Wang, J. Chen, I. MacLaren, and Y. Wen, Mater. Sci. Eng. A 712, 37 (2018).

41. G. Wang, H. Peng, P. Sun, S. Wang, and Y. Wen, Mater. Sci. Eng. A 657, 339 (2016).

42. R. Xiong, H. Peng, S. Wang, H. Si, and Y. Wen, Mater. Des. 85, 707 (2015).

43. C. Leinenbach, H. Kramer, C. Bernhard, and D. Eifler, $A d v$. Eng. Mater. 14, 62 (2012). 